among the quieter male patients at Quatremares, who are beneficially employed in garden work) almost nil. As we read of strait-jackets in which acute maniacs are confined for months, of torture inflicted (with the vain idea of controlling mania) by the continuous dropping of water on the head, of patierts lying on dank urinous-smelling straw, and of other similar horrors, we seem unconsciously transported (as Dr. Robertson remarks) to the ghastly scenes of old Hanwell or old "Bedlam." And what strikes us with especial force, in these days of improved dietetic science, is the scanty and poor diet afforded to the insane-a class of persons whose condition demands generous nutriment more than almost any other.

It cannot be believed that two distinguished psychologists like MM. Morel and Dumesnil are willing parties to the continuance of so barbarous a state of things. We suspect (as the writer of the report on which we base these remarks seems to do) that the interference of lay governors, and above all of stupid old réligieuses, has more to do with its continued existence; and we would call upon the more enlightened of our French brethren to shake off the fetters which these and such as these would place on free medical thought and practice, and to insist that such scandals shall cease to disgrace France in the midst of the nineteenth century. - The Lancet, August 19, 1865.

\title{
Condemnation before Trial.
}

Thovghtrol men have observed with pain and regret that of late an evil habit has grown up, on the part of certain newspapers, of passing judgment on a criminal before trial. Beginning comınonly with an avowal that they do not wish to prejudge the case, they proceed forthwith to lay stress on every circumstance of aggravation, to slur over, or sneer at, every imaginable circumstance of extenuation, and to wind up with certain violent appeals to the good sense of the community as to the urgent necessity of saving society from the dangerous consequences of humanitarian zeal. They are not quite so logically extravagant as the judge whose wig lately suffered so severely in its conflict with the quaker's hat, and who on one occasion reached such a height of philosophy as to tell a jury that he was not sure whether it was not more necessary to punish a lunatic than a sane man, as far as the welfare of society was concerned, but they are aiming well to reach that height. Perhaps the worst of the sinners in this regard amongst the newspapers now is not the 'Daily 'T'elegraph,' but the 'Saturday Review.' 'The 'Telegraph' sometimes shows that it has bowels of compassion and lucid intervals; but the chief glory of the 'Saturday Review' seems to be to display an unfaltering and unmitigated brutality, and 
Notes and News.

to be in a continual state of raving fury. The sublime arrogance of this journal, with the superficial show of learming and shallow pretence of philosophy, in which the immature precocity of some of its contributors is displayed, are generally amusing and harmless enough ;* but they are scarcely harmless when they are devoted to the deliberate purpose of fanning the popular resentment against some untried criminal, and of condemning, by means of gross misrepresentation, any sort of defence that the unhappy being may lave to offer at his trial. Jurors are chosen from the class of people who read the 'Saturday Review ;' and to strive in every possible way to prejudice their minds against the prisoner, before they enter the box, and to undermine his possible line of defence, is an unworthy thing on the part of any journal. We really cannot see that any one should do under an anonymous mask, and when writing for so many guineas a sheet, what an honorable man would not dare to do in his own name, and what a humane man would refrain from doing, however much protected by secresy. We know nothing more of the mental condition of the recent murderer, Southey, that what any one who has read. the newspapers knows, and certainly do not regard him with any compassionate feeling, but we-cannot but protest, in the name of justice and humanity, against the malignant spirit displayed by the 'Saturday Review' against a prisoner not yet put on his trial, and against the unfair means which it has adopted to secure his condemnation. Such course of action will not, we are sure, in the end be of service to the cause of justice; for, if continued, it must inevitably end in moving other journals to take up the opposite side with an equally unscrupulous violence. And if, when there is a question of a prisoner's sanity, a scientific journal should take upon itself to discuss the matter at length before the trial, and to pronounce a decided opinion, it may be doubted whether even the rabid fury of the 'Saturday Review' would suffice to neutralise the effect produced. Certainly the cause of justice would not gain by such proceedings.

We are sorry to sce that the bad example set has been only too quickly imitated by a paper which usually preserves a far higher tone than the 'Saturday Review.' The 'Pall Mall Gazette,' makes the following observations with regard to the last child murderess, who is now lying in prison awaiting her trial :- "We have neither the wish nor the inclination to prejudge the case of the miserable woman who has just killed her three children at Bankside, South-

* A short time ago a writer of one of those tedious articles in the 'Saturday Review,' which aim at being essays tinged with philosophy, said, when speaking of the tendency which now exists to "whitewash" the great actors of the past, that it only remained that some one should take Judas Iscariot in hand with that aim. Of course a writer in the 'Saturday Review' could not be expected to know what had long since been done by no less a person than De Quincey! 
wark ; but it is so certain that the plea of insanity will be raised in her defence that it is as well to call attention at once to the class of cases of which Esther Lack furnishes quite a typical example. She is clearly one of those weak-minded murderers of whom it is difficult to say whether or not they are so mad that they actually have no such power over themselves as to be able to control the homicidal frenzy. But the point which it is so inportant to press on public attention is this, that the legal question is not whether such persons are the victims of a homicidal frenzy of the nature of madness, but whether they can be so influenced by the dread of punishment as to be deterred from the actual murderous deed. The medical question as to their sanity is one thing; the legal question as to the possibility of terrifying them into self-control is another. The medical question has to be settled in the interests of science; the legal question is solely concerned with the interests of society. Society, which desires to protect itself from murder, has nothing to do with the psychological or pathological phenomena of sanity, except so far as to learn whether or not insane people can be deterred from killing whomsoever they feel disposed to destroy. For all practical purposes we want to know nothing about defects in the reasoning processes of the insane. What we want to know is, whether their imagination can be so impressed with the fact that insane murderers are hanged as to set up such a counter emotion as will silence the whispers of insanity prompting to murder. Mad people, the doctors tell us, are haunted with hideous thoughts which overcome all the suggestions of natural affection, of reason, and religion. We grant it; but in the common interest it is our aim to haunt their poor unhappy minds with some other hideous thoughts - whether of the gallows, or some other terrible vision-which will rise before their imaginations and crush the bloody impulses of disease. We repeat that we say and suggest nothing about the wretched woman Esther Lack. We only repeat that the duty of the law and its administrators is to save society from the crimes of the insane as well as from those of the sane. The law is not concerned with the moral nature of murder, but only with the murderer's acts. The stab of a weakminded assassin is as deadly as that of a man of iron will, and all we desire is to be protected from it."

These remarks hardly amount to anything else than a plain instruction to the jury who may have to decide upon the fate of Esther Lack to pronounce her guilty, though she may be insane. Then, if the unhappy lunatic be happily hanged at a time when many wise men doubt the policy of hanging any one, it may be that the mind of some other lunatic will be haunted with the terrible vision of the gallows, and that the bloody impulse of disease will be crushed. Although any one who has had a practical experience of insanity will at once recognise how absurdly fallacious such a notion 
is, yet it is very unlikely that any amount of argument would convince the writer in the 'Pall Mall Gazette' that he is guilty of a terrible mistake in judging of the insane consciousness from the revelations of a sane consciousness. In sober truth, however, he would not be one whit more unphilosophical were he to maintain that the fear of punishment should be used to prevent the convule sion of epilepsy or the spasm of chorea, because it may be successfully used to restrain the mischievous hands of a schoolboy. If he is truly anxious to judge the insane justly, he would do well for the future to try to conceive their mental state by the revelations of his own consciousness in dreams, or to accept the experience of those who have given their lives to the study of insanity.*

\section{The trial of a Lunatic for Murder.}

The following account of the trial of a lunatic for murder is interesting. The learned judge wisely stopped the trial, although it is probable that an ingenious counsel might have found in the prisoner's statements some ground for an argument that he knew the difference between right and wrong, as most lunatics notoriously do. "Something came over me. I seized my poor wife by the head, and knocked it against the flags again and again;" such is the articulate expression, as far as it can be articulately expressed, of that mental convulsion which in such case utters itself in homicide.

James Kelly was placed at the bar, charged with the wilful murder of his wife, Jane Kelly, at Butterworth, on the 1lth of June.

It appeared that the prisoner and his wife lived together at a place called Three Lanes-end, some three miles from Rochdale, and about a quarter of a mile from a place called Hollingworth Lake, a reservoir of the Rochdale Waterworks, upon which a steamboat and pleasure-boats were placed, having stalls and shops upon the edge, and which was turned to a place of public amusement. The prisoner by trade was a factory operative, but of late years had made his livelihood almost entirely by playing the accordion and concertina, and collecting money at the Hollingworth Lake, and he had married, within two years, a young woman named Royd, who had previously kept the school at the Three Lanes-end, and whose mother owned the cottage in which they subsequently lived. It appeared that the prisoner had at times given way to excessive drinking, as he himself said on one occasion, in consequence of frequenting the pleasure

- If anything could add force to these remarks, it is the result of the trial of Esther Lack, which has taken place since they were in type. The jury, before the termination of the evidence, expressed their opinion that she was insane; and in this opinion Mr. Justice Shee entirely concurred. 